\title{
Rethinking Bicameral Strength: A Three-Dimensional Approach
}

\author{
MEG RUSSELL
}

Bicameralism remains a common legislative arrangement, providing a classic potential check on political executives. But this potential is not always realised, leading scholars to ask which factors contribute to bicameralism that is 'strong'. One well-established analysis is that of Arend Lijphart, in his account of majoritarian and consensus democracies. This bases bicameral strength on two dimensions: 'symmetry' of the two chambers' formal powers and 'incongruence' of their composition. Other theorists reason in similar ways. But recent British developments, backed by evidence from other states, expose flaws in this approach. A more convincing theory must be 'three-dimensional', recognising the centrality of perceived legitimacy to bicameral strength. Legitimacy is fundamental to understanding bicameralism, due both to the composition of some second chambers and to the role of all such chambers in challenging democratically elected first chambers. Lijphart did note that legitimacy affected the dynamics of bicameralism, but its role is both more central, and significantly more complex, than he suggested.

Keywords: bicameralism; legitimacy; Lijphart; House of Lords; Canada; Australia.

Despite its ancient origins, bicameralism remains a common legislative arrangement. In October 2011 the Inter-Parliamentary Union recognised 190 national legislatures, of which 78 were bicameral. ${ }^{1}$ Bicameral legislatures are diverse, and exist in varied political contexts. In many places they are accepted and respected; but bicameralism is also often questioned, even in long-standing and stable democracies.

Bicameralism provides one of the most obvious potential institutional checks on the power of political executives. Hence it is integral to some of the best-established modern analyses of different constitutional forms. Given the diversity of existing bicameral arrangements, and the weakness or instability of some second chambers, political scientists have focused in particular on which features create bicameralism that is 'strong': in terms of a second chamber that exerts real influence on the policy decisions of the executive and first chamber.

An important account of bicameralism in general, and particularly of bicameral strength, is that provided by Arend Lijphart (1984, 1999a). Lijphart's classification of bicameral systems is often the starting point for comparative (for example, Druckman \& Thies, 2002; Llanos \& Nolte, 2003; Siaroff, 2003) as

The Journal of Legislative Studies, 2013

Vol. 19, No. 3, pp. 370-391, http://dx.doi.org/10.1080/13572334.2013.773639

(C) 2013 The Author(s). Published by Taylor \& Francis.

This is an Open Access article distributed under the terms of the Creative Commons Attribution License (http://creativecommons.org/licenses/by/3.0), which permits unrestricted use, distribution, and reproduction in any medium, provided the original work is properly cited. The moral rights of the named author(s) have been asserted. 
well as single country studies (for example, Flinders, 2005). For Lijphart, bicameralism forms one of the 10 institutional features used to distinguish between his well-known categories of 'majoritarian' and 'consensus' democracies. Consensus democracies, which demand broader consent for changes to policy, are associated with 'strong' bicameralism, while majoritarian democracies are associated with unicameralism or 'weak' bicameralism. Lijphart thus goes on to explore which institutional features result in bicameralism that is 'strong'. He concludes that there are two key dimensions, termed 'symmetry' and 'congruence'. The first of these largely reflects the second chamber's formal powers, while the second focuses on the extent to which its composition differs from that of the first chamber.

Other authors draw attention to the same two dimensions when explaining bicameral strength. George Tsebelis' (2002) theory of 'veto players' explicitly sought to differ from Lijphart, by giving greater prominence to political parties. He defined veto players as 'individual or collective actors whose agreement is necessary for a change of the [policy] status quo' (2002, p. 19). Second chambers were potentially important examples, but to qualify they required both a veto power and a partisan control distinct from that of the first chamber. Tsebelis' emphasis on the importance on parties echoed the account previously provided by Giovanni Sartori. Sartori (1994) had focused on the same two dimensions, suggesting that bicameral strength will be greatest when the second chamber enjoys significant formal powers and a distinct partisan composition from the first chamber.

That there are two key dimensions influencing bicameral strength - formal powers and compositional distinctiveness to the first chamber - is therefore widely accepted. However, Lijphart $(1984,1999$ a) also included reference to a third factor, noting that a second chamber's legitimacy may affect its ability to use its power. Legitimacy was nonetheless treated only as a contributor to the symmetry dimension, rather than as an explicit dimension in its own right (and was defined very narrowly, as discussed below). The central argument in this article is that a convincing theory of modern bicameralism must instead be 'threedimensional', and take explicit account of second chambers' perceived legitimacy. There are obvious reasons why second chamber legitimacy may be questioned: in many cases due to the composition of these chambers, but also to their fundamental role in challenging elected first chambers. Second chamber legitimacy is not only more important, but also significantly more complex, than Lijphart indicated.

The article begins by briefly reviewing the two established factors contributing to second chamber strength, then summarises the existing literature on the legitimacy of political institutions and its relevance to bicameralism. It then presents three case studies. First, of the British House of Lords, which has been very influential on the development of theories of bicameralism, as demonstrated by its treatment by all three authors cited here (Lijphart, 1984, 1999a; Sartori, 1994; Tsebelis, 2002). Recent reforms to this chamber's composition, and resultant changes to its behaviour, demonstrate the importance of perceived legitimacy to second chamber strength, and that such legitimacy is based on a 
complex range of factors. The two further cases, of the Australian and Canadian Senates, are presented more briefly, and corroborate the argument. The final section of the paper proposes a 'three-dimensional' approach to bicameral strength, more widely applicable than existing theories.

\section{The Two Established Dimensions of Bicameralism}

When considering the factors influencing bicameral strength, the most obvious explanatory variable is the formal power of second chambers, which is largely specified in constitutions. This differs widely (Patterson \& Mughan, 1999; Russell, 2000; Tsebelis \& Money, 1997). Unlike first chambers, second chambers even in parliamentary systems tend not to have the power to remove executives (though Italy is an exception). They may variously have powers for example over appointments, treaties or questioning ministers. But their clearest and most universal power is that over legislation. Even here there is wide variation, ranging between the US Senate or Swiss Ständerat's 'coequal' right of veto shared with the lower house, to the very limited delaying power of the Polish or Irish Senates. ${ }^{2}$ Examples of moderate power include the Japanese and Indian parliaments, where special mechanisms are required to resolve intercameral disputes. ${ }^{3}$ Within countries, variation is also relatively common between different kinds of bills. For example, in Germany and Austria, where the second chamber represents regional interests, it has significantly greater power over legislation on regional matters. Likewise, many second chambers have less power over financial than ordinary legislation, and more power over constitutional change.

Lijphart (1984, 1999a), Tsebelis (2002) and Sartori (1994) all ascribe significant importance to second chambers' formal powers. Understandably they conclude that, all things being equal, second chambers with the greatest formal powers will have the best chance of influencing the policy process. Some authors go further, with formal modelling approaches often effectively treating the presence of a coequal legislative veto as a condition for bicameralism (for example, Riker, 1992; Rogers, 2001). ${ }^{4}$ Tsebelis, while his key text cited here focuses on veto players (2002), did not actually go this far, acknowledging elsewhere that even second chambers with quite limited formal powers can be influential (Tsebelis \& Money, 1997). Comparative empirical studies support this view (Druckman \& Thies, 2002; Heller, 2001). In some circumstances the threat of delay or public embarrassment over ill-considered legislation may alone persuade executives to concede to second chamber demands. In other words, very strong formal powers may not always be necessary. But they may also not be sufficient: which is where the other dimensions - of incongruence and, this paper argues, perceived legitimacy - become important.

It is widely acknowledged that bicameral relations will be affected by the extent to which the two chambers' memberships are distinct. A central rationale for bicameralism has often been inclusion of members representing different 
perspectives to those in the first chamber. The classic example is US bicameralism, where the founders drew on the traditional benefits of 'mixed government', as advocated by Montesquieu. His mixed government ideal was based on study of Westminster: a class-based system where the House of Lords represented the nobility and the House of Commons a wider citizenry. At that time similar elite-based second chambers existed in various other European states (Tsebelis \& Money, 1997). ${ }^{5}$

The elite model of bicameralism has now very much declined and been overtaken by the territorial model. Here the first chamber represents citizens on an equal franchise while the second chamber represents territorial units, often disproportionately to population. The classic example is again US bicameralism, with equal Senate representation for states irrespective of population size. But variants exist in most other federal bicameral states (for example, Brazil, India, Malaysia), and some non-federal states (Italy, France). Lijphart (1999a) places particular importance on this form of incongruence, which he demonstrates by using the Gini index to capture territorial over- or under-representation.

However just as territorial representation eclipsed elite representation over time, it can be argued that in practice partisan differences now often eclipse official territorial distinctions (Russell, 2001). As already indicated, both Tsebelis (2002) and Sartori (1994) instead emphasise the role of party balance in incongruence. Thus Tsebelis characterises second chambers as 'institutional veto players', but suggests that when such players are controlled by the same partisan majority as other players whom they seek to influence (most obviously the executive and first chamber) their impact is diminished, to the extent that they are effectively 'absorbed'. This means that the number of veto players in a given system can vary over time, as partisan control of institutions changes. In short, a second chamber sharing the same partisan makeup as the first chamber and/or executive may have little policy effect.

The three theories' distinct approaches to membership incongruence cause them to make different predictions. For example, a study applying Lijphart's theory across Latin America, which took no account of partisan balance, suggested that Latin American second chambers' veto powers and clear territorial incongruence resulted in bicameralism that was uniformly strong (Llanos \& Nolte, 2003). But a detailed study of the Brazilian Congress found that significantly more executive bills in fact passed when the president's coalition had a Senate majority than when it did not (Hiroi, 2008). Likewise, a wider comparative study has found that governments lacking second chamber majorities are significantly less durable, despite most executives not formally depending on the confidence of second chambers (Druckman \& Thies, 2002). The evidence therefore suggests that it is partisan incongruence that matters most.

However, in the same way as some authors point out that strong formal powers may not be essential, others suggest that "congruent house preferences do not necessarily vitiate the case for bicameralism' (Rogers, 2001, p. 125). Even two apparently identical groups may make different decisions. Such 
chambers may thus still fulfil a minimal bicameral function of 'quality control' (Tsebelis \& Money, 1997, p. 40).

\section{A Third Dimension: Perceived Legitimacy}

The central argument in this article is that, while the two dimensions above are undoubtedly important predictors of de facto bicameral strength, the addition of a third predictor is necessary: perceived legitimacy. While authors such as Tsebelis and Sartori have overlooked this dimension completely, Lijphart did mention it in his scheme $(1984,1999$ a). He treated legitimacy only as a contributor to the symmetry dimension, and specified it in very limited terms. Nonetheless he made an important point: that a lack of legitimacy may render a second chamber unable in practice to make full use of its powers.

It is surprising that legitimacy does not feature more prominently in existing treatments of bicameralism. Its absence from Tsebelis' (2002) theory can be explained by the fact that most second chambers with veto powers, both inside and outside the US, are directly elected. But Money and Tsebelis (1992), noting that most US scholars overlook the impact of legitimacy, nonetheless suggested that 'efforts to analyse, explain, and make more concrete the concept of legitimacy will enable future research to produce a more comprehensive understanding of bicameral legislatures' (p. 40). The present article seeks to fill that gap.

Legitimacy is of obvious relevance when discussing bicameralism, for two principal reasons. The first relates to second chambers' composition. As already indicated, bicameralism has pre-democratic origins. Even today the majority of national second chambers include either unelected members or members elected 'indirectly' (for example by provincial legislators). Of the 78 such chambers in existence in October 2011, just 21 were wholly directly elected. ${ }^{6}$ In a democratic age there are obvious questions about remnants of the elite model in particular.

But there is a second and more universal reason to question the legitimacy of second chambers. This concerns their fundamental role of contesting the decisions of first chambers, themselves generally elected on a universal equal franchise. Second chambers hence potentially challenge majority rule. This inherent tension in bicameralism was noted by John Stuart Mill (1861/1998), who suggested that with two chambers '[o]ne being supposed democratic, the other will naturally be constituted with a view to its being some restraint upon the democracy. But its efficacy in this respect, wholly depends on the social support which it can command outside the House' (p. 386).

Legitimacy is a contested, and widely discussed, concept in political science. Existing approaches may be broadly divided into two camps. Authors in the minority camp take a normative approach, setting down criteria against which they believe the legitimacy of institutions or regimes should be judged (for example, Beetham, 1991; Simmons, 2001). In contrast, the majority of social 
scientists take an empirical approach, instead seeing legitimacy as a sociological phenomenon. Here if 'people hold the opinion that existing institutions are appropriate or morally proper, then those institutions are legitimate' (Dogan, 1995, p. 57). Building on the work of Weber (1957) and Lipset (1959), this allows scholars to measure legitimacy objectively in terms of polled opinion. Lijphart (1999a) employed a straightforward definition of democratic legitimacy, concluding that '[s]econd chambers that are not directly elected lack the democratic legitimacy, and hence the real political influence, that popular election confers' (p. 206). This treats direct election as a proxy for legitimacy, which places Lijphart in the normative, minority, camp.

A discussion of which of these two approaches best defines 'legitimacy' per se is not what matters in the current context; our concern is with defining the potential third variable that influences second chambers' de facto strength. As Mill (1861/1998) suggested, here 'social support' seems to be the key. Regardless of how a chamber is composed, if it has support it is more likely to demonstrate the confidence to challenge government, and subsequently to have its interventions taken seriously. ${ }^{7}$ The notion of 'support', by both citizens and elites, is central to Michael Mezey's (1979) well-known classification of legislatures' importance in the policy process, which makes it one of the two dimensions influencing the policy strength of these institutions (alongside their formal powers). 'Support' is a less contentious term than 'legitimacy', with no normative undertones. In the remainder of this article the third dimension is nonetheless referred to as 'perceived legitimacy'. This is in line with most social scientists, and to an extent with Lijphart's terminology, but avoids suggesting that institutions perceived as legitimate necessarily are legitimate in a normative sense. ${ }^{8}$

Accepting that perceived legitimacy may matter to bicameral strength is only the first step. As Saward (1992) suggests, 'the question goes beyond what people do believe, toward "what good reasons might lead people to believe?"' (p. 44). That is, in what circumstances will a second chamber be perceived as legitimate by the public and elites? Here there is much theoretical and empirical literature to draw on, from well-established debates about democratic bodies and more recent consideration of 'non-majoritarian institutions'. This latter literature is clearly highly germane, given second chambers' role as non-majoritarian, or even anti-majoritarian, bodies.

Within this extensive literature, three distinct contributors to perceived legitimacy are cited. These have been termed 'source', 'procedural' and 'substantive' legitimacy (Bodansky, 1999), or 'input', 'throughput' and 'output' legitimacy (Papadopoulos \& Warin, 2007), respectively.

- Source or input legitimacy is concerned with the composition of institutions, and clearly may include democratic legitimacy, achieved through election. But many scholars recognise, for example in the context of international bodies, that "ddemocracy" is only part of the story of political legitimacy' (Menon \& Weatherill, 2008, p. 401). Where non-majoritarian institutions are 
concerned, other 'standards' may be required (Majone, 1998). These bodies have often been designed explicitly to complement existing democratic institutions, and thus to have a 'competing' form of input legitimacy. This can come for example through a body's ability to contain differences between groups (Lipset, 1959), through the body being 'like those whom it governs, in terms of its national, racial, religious or ideological identity' (Barker, 1990, p. 51), or through the expertise of its members (Vibert, 2007). These approaches describe precisely the kinds of features that are often designed into second chambers, so are highly relevant to bicameralism.

- Procedural (or 'throughput') legitimacy has been widely discussed in particular with respect to courts. These may be considered legitimate precisely because their procedures are less political, and viewed by the public as more 'fair' than those of elected institutions (Baird, 2001; Tyler \& Rasinski, 1991). Consequently such bodies may even come to enjoy greater popular support than elected legislatures (Hibbing \& Theiss-Morse, 1995). Again second chambers - particularly those somewhat distant from the electoral process - may build similar reputations. Second chambers are often known for their relatively less party-political ethos, and for their careful deliberation and policy scrutiny, contrasted with first chambers.

- The third concept is 'output' legitimacy, based on policy decisions. This is again widely applied both to courts and to international organisations (Beetham \& Lord, 1998; Majone, 1998). It is suggested that while these institutions may lack conventional input legitimacy, they can develop complementary legitimacy to democratic state institutions through the popularity of their policy interventions (Menon \& Weatherill, 2008). The same may apply to challenges by second chambers over unpopular or ill-thought-through policy, even when it has first chamber support.

These three contributors to perceived legitimacy are not mutually exclusive, and indeed are interconnected. For example, it has been noted that perceptions of the courts' procedural or input legitimacy may confer legitimacy on their output in terms of policy decisions (Mondak, 1994). Perceptions of second chamber legitimacy could therefore result from input, procedural or output factors, with various feedback loops operating between the three.

This discussion helps clarify that legitimacy, while potentially important to de facto second chamber strength, does not fit under either of the two established dimensions of bicameralism. Lijphart (1984, 1999a), who is the only theorist to have given legitimacy a role, saw it as dependent on second chambers' composition, but then used this in certain cases to downgrade their formal powers. Neither of these steps withstands closer inspection. Legitimacy is clearly independent of a chamber's formal constitutional powers, neither affecting them nor being affected by them: instead it has implications only for the extent to which these powers are actually used. In addition, as indicated here, the perceived legitimacy of a second chamber may depend on more than its composition alone; 
potentially being affected by how it acts, and by broader factors such as political culture. We should therefore proceed on the basis that perceived legitimacy is indeed a third dimension, and hence could be a third independent variable in explaining bicameral strength. We now turn to some case studies to explore whether and how this is the case in practice.

\section{UK Bicameralism Post-1999: A Curiously Stronger Second Chamber}

The roots of the House of Lords lie in the elite model of bicameralism. From the fourteenth century, English bicameralism principally reflected class interests, with the second chamber representing the nobility and the church. As the House of Commons franchise widened over time the House of Lords appeared increasingly anachronistic. A major intercameral conflict in 1909 resulted two years later in its veto being largely replaced with a delay power, which was reduced in 1949 to around one year on most bills. Membership reform then followed in 1958, when appointed 'life peers' were introduced, to sit alongside the traditional 'hereditary peers' (who passed their seats down the family line). Further reform in 1999 then removed most hereditary peers. This left a chamber largely made up of members appointed to serve for life by successive prime ministers. Such appointments continue, with new peers for the three main parties being created broadly in line with these parties' electoral strength, and non-party members chosen by an independent commission (Shell, 2007; Russell, 2013).

Lijphart $(1984,1999$ a) considered the House of Lords before its reform in 1999, and it was clearly influential on his theory. It is a classic example of the elite model, and also demonstrates how a chamber that is powerful on paper can be undermined by lack of legitimacy. As early as the 1860s Bagehot had noted how despite the Lords' veto its de facto power had significantly declined, so that it had 'become a revising and suspending House' (1867/2001, p. 79). After 1949 the chamber's formal delay power remained moderately strong in comparative terms. But in the 1940s the 'Salisbury convention' also developed, which held that the Lords should not seek to block policies appearing in the governing party's election manifesto. By the late twentieth century the chamber's powers had fallen into such disuse that scholars suggested that it had 'embraced a voluntary impotence' (Shell, 1999, p. 203).

This is what Lijphart sought to capture. His classification of British bicameralism appeared perfectly accurate at the time: despite the House of Lords' formal powers, he concluded that its lack of democratic legitimacy made the two chambers 'extremely asymmetrical' (1984, p. 99). ${ }^{9}$ Nonetheless the chambers were considered incongruent, since the Lords overrepresented minority interests, where ' $[\mathrm{t}]$ he overrepresented minority ... is, of course, the nobility' (Lijphart, 1984, p. 98). Combining the two dimensions, British bicameralism was judged to be relatively weak. ${ }^{10}$

Sartori (1994) and Tsebelis (2002) drew similar conclusions, but for different reasons. Both ostensibly considered party balance to be the key to the 
incongruence dimension, and here the conclusion might have been expected to differ over time. The Conservative Party benefited from the support of most hereditary peers, so permanently dominated the House of Lords prior to 1999. Even when the chamber was at its most timid, governments of the left thus faced greater resistance than governments of the right. But Sartori (1994) simply concluded that Britain had 'extremely feeble bicameralism ... [that] shades into unicameralism' (p. 188). This conclusion may have been essentially correct, but it was not actually justifiable on a two-dimensional analysis alone. Only the Lords' lack of legitimacy, which he did not explicitly acknowledge, could explain its de facto weakness during periods of Labour government.

Tsebelis' (2002) veto player theory explicitly allowed the powers of a chamber to vary with party balance. But he did not apply this in the case of Britain, which he considered essentially unicameral due to the Lords' lack of veto power. This analysis was, in fact, erroneous. The Lords always retained an absolute veto over those (roughly one-third of) bills which began their parliamentary passage there rather than in the Commons, as the 1911 and 1949 Acts made no mention of such bills. Its weakness came from the fact that this power was in practice never used. So, again, Tsebelis was correct to place the Lords in the category that he did, but his reasoning was flawed. The chamber's difficulty was its legitimacy, which his theory did not take into account. The old House of Lords therefore illustrates some difficulties with the accounts of all three theorists, but it was Lijphart who recognised its fundamental weakness.

New problems present themselves, however, when considering the post-1999 House of Lords. By Lijphart's logic the removal of most hereditary peers reduced the incongruence between the chambers (making them more similar in social terms), whilst doing nothing to boost the Lords' legitimacy. The expected effect would therefore be a weakening of bicameralism. One scholar, using a strict application of Lijphart's theory, predicted exactly this (Flinders, 2005). However, the reality has proved quite different: many scholars have now noted that the post-1999 Lords has become significantly more confident, assertive and influential than its predecessor (for example, King, 2007; Russell, 2010; Shell, 2007). The Lords inflicted over 450 defeats on government legislation between 1999 and 2010, and analysis shows that its policy position was often accepted following such defeats (Russell \& Sciara, 2008). ${ }^{11}$ The chamber still did not use its powers to the full, but nonetheless became far bolder in challenging the government, particularly over protection of civil liberties and other constitutional matters. Consequently the government changed its own internal procedures to take greater account of the Lords' views at an early stage, in order to avoid defeat (Russell, 2010). In short, contrary to Lijphart's theory, there seems little doubt that British bicameralism was strengthened by the 1999 reform.

This development is clearly counterintuitive. It is not explicable in a twodimensional framework, as the Lords' formal powers remain unaltered and, following the departure of most of the 'nobility', Lijphart would judge that the 
chambers became more compositionally similar. Tsebelis' theory offers some clues, given its emphasis on the importance of partisan balance. Here the removal of the hereditary peers ended the Conservative Party's dominance, leaving the two main parties with roughly equal numbers of seats, and the balance of power held by the third party (Liberal Democrats) and a large group of independents. The Liberal Democrats thus became a veto player, and decisive in government defeats (Russell \& Sciara, 2007). But this explanation alone cannot explain the Lords' increased assertiveness. The pre-1999 House of Lords was frequently opposition-controlled during periods of Labour government, but did not fully use its powers, and was thus considered by Tsebelis to be weak. To explain the post-1999 change, a three-dimensional approach, taking account of perceived legitimacy, is necessary. This factor not only explains the chamber's previous timidity, but also its new assertiveness. Yet we must clearly look beyond Lijphart's emphasis on democratic legitimacy; we can therefore usefully return to the three sources of perceived legitimacy introduced above.

First, in terms of input legitimacy, the 1999 reform, whilst not conferring any form of democratic mandate, resulted in two important changes. The most obvious was that it ended the anachronism of inherited parliamentary seats. This left a chamber where all members were chosen by a merit principle: the great majority being life peers appointed for their achievements, plus 92 remaining hereditary peers who were elected by their colleagues. This was rhetorically important for Labour at the time of reform, leading the government to claim repeatedly that the new chamber was 'more legitimate'. ${ }^{12}$ Secondly, the resultant changes to the chamber's party balance were important to how it was perceived. The new and more balanced House of Lords was very different to and far more defensible than its Conservative-dominated predecessor. Importantly, it was also very different to the House of Commons, where elections by single-member plurality resulted in dominance by single-party majority governments between 1945 and 2010, generally on a minority of the popular vote. For example, in 2005 Labour's 35 per cent vote share was rewarded with 55 per cent of Commons seats. Post-1999 the Lords, while not elected, ironically had a partisan makeup which more closely reflected public voting patterns than did the House of Commons. This brought the relative legitimacy of the elected chamber into at least some doubt: particularly given the presence of an active lobby in Britain proposing proportional representation (PR) for that chamber. The Liberal Democrats - being the political party most closely connected to the PR lobby - thus began vocally to assert the right of the more proportional House of Lords to defeat controversial government legislation. ${ }^{13}$

Hence both the Labour government and the newly pivotal third party publicly proclaimed the greater legitimacy of the reformed House of Lords: clear evidence that perceptions amongst some political elites had changed. This same change is seen in evidence from elite surveys. For example, in a 2007 poll 76 per cent of members of the Lords believed that the chamber's 'legitimacy' had 'increased' post-reform. ${ }^{14}$ In a 2004 survey, a majority of MPs said the same. ${ }^{15}$ 
As indicated above, perceptions matter not only amongst elites, but also amongst the wider public. And procedural and output legitimacy may also be important to how a second chamber's interventions are perceived. Public opinion data on the House of Lords is relatively limited, and no reliable time series data exists. Polls also demonstrate that the House of Lords is of low salience, and relatively poorly understood. ${ }^{16}$ But the available data suggest that the public view the practices of the post-1999 chamber relatively positively. For example, a MORI poll in May 2005 found that 66 per cent of respondents believed (contrary to the Salisbury convention) that where government manifesto bills had 'little public support' it was 'justified for the House of Lords to block' them. ${ }^{17}$ Another poll in October 2007 found that a majority believed 'the House of Lords generally carries out its policy role well', which (even prior to the 2009 MPs' expenses crisis) was slightly more than said the same about the House of Commons. At the same time, only around a third of respondents believed that 'the process for choosing members of the House of Lords is a good one', while two-thirds believed that this was true of the House of Commons. ${ }^{18}$ Hence the chamber was able to enjoy some perceived procedural and output legitimacy, whilst nonetheless lacking democratic input legitimacy. ${ }^{19}$

The public depends largely on the mass media for information about the operation of parliament, and the opinion of media elites is thus likely to be influential. An analysis of over 600 national newspaper editorials mentioning the House of Lords from 1999 to 2012 found that media representations of the chamber presented mixed impressions of the chamber's legitimacy (Russell, 2013). Articles referring to the Lords' composition method tended to present its legitimacy negatively, but with respect to other aspects of input legitimacy (for example, party balance, presence of independent members and experts) coverage was more positive. References to procedural legitimacy (for example, the Lords' relatively nonpartisan ethos) were similarly largely positive. With respect to output legitimacy, all newspapers tended to support the Lords when it challenged government policy, and the growing frequency of these challenges made such reporting increasingly common. For example, on 12 March 2005, when the chamber had just blocked a Prevention of Terrorism Bill, the left-leaning Independent suggested that 'it is appropriate that the House of Lords, unelected though it is, should have cast itself as the guardian of our rights and freedoms', while the right-leaning Daily Mail declared the outcome 'a victory for parliament and particularly a robust and courageous House of Lords'.

The Lords' recent history therefore holds important lessons for understanding bicameral strength. It supports the central propositions in this article that perceived legitimacy matters, and that its sources are more complex than has previously been assumed. The post-1999 House of Lords is widely perceived as more legitimate than its predecessor, despite remaining unelected. Its unelected nature undoubtedly still discourages it from using its full powers, and its members demonstrate considerable restraint in challenging government. As Beetham and Lord (1998, p. 9) point out, legitimacy is "not an all-or-nothing 
affair, but a matter of degree', and the Lords is certainly not seen as fully legitimate, meaning that it is not fully confident to use its powers. But the chamber's days of 'voluntary impotence' are clearly over. Input legitimacy was enhanced by two aspects of the 1999 reform: the departure of hereditary legislators and the advent of a more proportional party balance. The chamber also enjoys some procedural legitimacy, due to its deliberative and relatively non-partisan atmosphere, and growing output legitimacy through challenging controversial government policies. Thus, while Lijphart was correct to draw attention to legitimacy (a focus based in large part on his observation of the pre-1999 House of Lords), his treatment of it was underdeveloped.

\section{Supporting Evidence: Canada and Australia}

The British case already provides a clear indication of some of the weaknesses in existing theories. A two-dimensional approach is not sufficient to explain the recent resurgence of the House of Lords. Even Lijphart's theory, while touching on legitimacy, fails at this task. The Lords therefore provides a sufficiently important counter-example to indicate a need for theory to be revised. But evidence from other established bicameral democracies may help to add greater clarity, in terms of the role of perceived legitimacy in second chamber power, and its sources. Examples are thus provided from Canada and Australia, based on the more limited evidence available.

\section{Canadian Bicameralism: An Appointed Senate under Siege}

The appointed Canadian Senate, whose composition has changed little since Canadian federation in 1867, is ostensibly similar to the House of Lords. Members are chosen by the prime minister and previously served for life, but now retire aged 75. A vestigial property qualification (of \$4000) remains, and members must be at least 30. The Senate therefore maintains key aspects of the elite model. But it also has important features of the territorial model, as members officially represent the provinces, despite being centrally appointed.

Unlike the Lords, the Senate has the same right to introduce, amend or reject ordinary bills as its counterpart, the Canadian House of Commons. Only on financial legislation and constitutional amendments does it lack an absolute veto, and there is no mechanism for resolving intercameral disputes. Compositionally there is also an important difference to Britain, as there is no convention in Canada that the prime minister should respect a need for party balance when choosing appointees, so new senators are normally drawn only from the governing party. Governments taking office have therefore often faced a politically hostile Senate, only to gain a partisan majority over time.

The Senate has not been as prominent as the Lords in the formation of theories of bicameralism. Nonetheless it is discussed by Lijphart, who judges Canadian bicameralism to be weak to medium (that is, similar or only slightly stronger than that in Britain). This lowly status, given the Senate's veto and its high 
territorial Gini index, derives wholly from its lack of legitimacy. Applying this logic, we would expect the Senate to be weak all of the time. In contrast, applying the theory of Tsebelis (2002) we would expect the Senate to be a veto player when opposition-controlled in the early years of a government's life, but later to become 'absorbed'. In practice neither of these competing predictions turns out to be entirely correct, but again it is Lijphart who gets closest to the truth.

Legitimacy features heavily in debates on the Canadian Senate, which has faced calls for reform almost since its creation. Canadian experts point out that 'doubts about the Senate's legitimacy are raised constantly' and suggest that this 'is perhaps the most significant impediment that limits the Senate in having greater influence' (Franks, 2003, p. 185). ${ }^{20}$

The Canadian Senate's most assertive period was in the 1980s. The Progressive Conservatives won a large first chamber majority in 1984, following almost 21 unbroken years of Liberal government. But the new government faced an overwhelmingly Liberal Senate. There followed a string of intercameral confrontations, including long delays over a controversial Drug Patent Bill and refusal to pass a free trade bill which forced a general election in 1988. In 1990, after further difficulties over a proposed goods and services tax, Prime Minister Mulroney used a constitutional provision never used before to appoint eight additional senators and create a government majority (Russell, 2000). Thereafter confrontation abated. This episode showed how a change to partisan balance had potential to alter the Senate's de facto power. Yet these were 'unusually partisan confrontations ... the like of which had never been seen before' (Franks, 2003, p. 155). During earlier periods of opposition control the Senate had generally been viewed as weak, some even suggesting that its 'veto power [had] now become little more than a reserve power' (Forsey, 1982, p. 272).

In the 1980s Liberal senators sought to overcome concerns about the chamber's input legitimacy and instead exploit output legitimacy by opposing controversial government policies. For example, a 1987 poll found public opinion narrowly balanced in favour of the Senate blocking the Drug Patent Bill. $^{21}$ Nonetheless Canadian specialists judge that these attempts largely backfired. The media presented Senate interference as 'partisan meddling', which 'contributed to the growth of the public perception of the Senate being illegitimate' (Franks, 2003, p. 165). In 2006 the Conservatives again gained power to face a strongly Liberal Senate following 13 years of Liberal rule; but there have been no similar confrontations. Senators appear to have reverted to their previous timidity, amidst legitimacy concerns that threaten their very existence. Prime Minister Harper has consistently talked down the Senate's legitimacy, and threatened Senate reform.

The Canadian case thus confirms Lijphart's (1984, 1999a) claim that even incongruence of composition combined with extensive formal powers are not enough to make a second chamber strong, unless its policy interventions are perceived as legitimate. But it was too easy to assume, as he did regarding the House of Lords, that the Senate's weakness derived solely from its lack of election. 
As the British case post- 1999 has demonstrated, some unelected chambers can be seen as more legitimate than others. The Senate's unelected nature is certainly controversial, but concerns in Canada about its legitimacy also focus on two other input factors. The first is the Senate's inadequacy as a territorial chamber. Senate reform proposals which have come closest to being adopted were part of larger constitutional reform packages, designed to resolve the territorial tensions which dominate Canadian politics; including the failed Meech Lake Accord of 1987 and Charlottetown Accord of 1992. More recently campaigners have called for a 'Triple-E' Senate - 'elected, effective and equal' which would require a significant redistribution of seats between the provinces to benefit the west of Canada. For many Canadians the Senate is thus a symbol of unresolved territorial disputes. In addition there are concerns about the nature of the appointments system: that the prime minister - rather than provincial governments - is responsible for choosing senators, and this patronage is used in a highly partisan way (Franks, 1999). In contrast to the Lords, the chamber tends to be dominated either by government or opposition, with few minor party or independent members. Even an elected Senate with similar territorial or partisan imbalances might suffer similar legitimacy problems. For evidence on this point we turn to our third example, of Australia.

\section{Australian Bicameralism: Legitimacy within Limits}

The Australian Senate, though also part of the 'Westminster family', looks very different to its British and Canadian counterparts. Since Australian federation in 1901 it has been directly elected, with equal representation for each of the six states. ${ }^{22}$ It therefore strongly follows the territorial model, as influenced by the US. It has co-equal powers with the lower house over most legislation; the only formal means of resolving intercameral disputes is a 'double dissolution' to re-elect both chambers, followed if necessary by a joint parliamentary sitting. The most (in)famous episode in the Senate's history was its blocking of a budget bill in 1975, which forced a general election and change of government.

For Lijphart, Australia was an archetypal example of 'strong' bicameralism. Equal state representation results in a high Gini index, while the two chambers have symmetrical formal powers. There is no difficulty with democratic legitimacy. We would therefore expect the Senate to be a significant policy actor. The chamber is also a potential veto player for Tsebelis (2002), dependent of course on its partisan composition. Sartori (1994) agreed, and cited the 1975 crisis as an example of how bicameralism can be too strong.

The main focus of this article is legitimacy, but the Australian case also presents an opportunity to reflect briefly on the key components of compositional incongruence for strong bicameralism, as existing theories emphasise different factors: either territoriality (Lijphart) or partisan balance (Sartori and Tsebelis). In Australia it is clearly the latter that matters most. Until 1948 the Senate was, like the lower house, elected using a majoritarian system that exaggerated representation of the winning party: for example, in 1947, 33 of the 36 senators 
were Labor. A proportional voting system was then introduced, which led to minor parties and independents gaining seats, and government majorities becoming unusual. From 1981 to 2005 the Senate was consistently a 'hung' chamber, with the balance of power held by minor parties and independents. Australian commentators note that pre-1948 the chamber was relatively peripheral, but the introduction of PR saw it 'transformed' into a central policy actor (Sharman, 1999, p. 149). This already indicates a problem with Lijphart's reasoning, as territorial differences alone were not enough for bicameralism to be strong pre-1948. ${ }^{23}$ Recent experience, from when John Howard's Liberal-National government gained a narrow Senate majority in 2005, corroborates. Once the government gained a majority the proportion of opposition amendments approved by the Senate declined sharply, committees were given far less time to consider bills, and oversight committees were abolished (Evans, 2008). In other words, in Tsebelis' terms, the chamber was effectively 'absorbed'. Subsequently Howard lost a general election to Labor in 2008, and the Senate returned to no overall party control, and resumed a more active role.

But the Australian system also holds important lessons about perceived legitimacy. Since it is directly elected, Lijphart's theory would not predict this to be an issue. But in fact the Senate's legitimacy - including its input legitimacy - is regularly and quite aggressively questioned. Australian Prime Minister Paul Keating famously referred to senators as 'unrepresentative swill', on the basis of the equal representation of states in the Senate irrespective of widely differing populations. ${ }^{24}$ More recently Cabinet Secretary John Faulkner repeated this point, emphasising that the Senate 'does not reflect that fundamental, democratic, Chartist principle of one vote, one value'. ${ }^{25}$ This chimed with the words in a classic text on Australian government which suggested that, ' $[\mathrm{t}]$ he fact that the Senate is directly elected by adult suffrage does not mean ... [that] action by a Senate majority hostile to the Government of the day is any the less an affront against the essential democratic principle of majority rule' (Crisp, 1983, quoted in Bach, 2008, p. 548). Hence the extreme territorial incongruence in Australian bicameralism - that is, the equal state representation that Lijphart considered so important - places limits on perceptions of the Senate as legitimate.

Other input factors nonetheless boost perceptions of the Senate's legitimacy, alongside output factors concerning its policy interventions. In debating bicameralism the issue of 'mandate' is central in Australian politics (Goot, 1999). While government claims a mandate to govern unimpeded, elected non-government senators claim a mandate to oppose, particularly on unpopular policies. This results in a constant 'clash of mandates' (Mulgan, 2000, p. 320). Evidence suggests that the public support, and indeed encourage, such tension. 'Splitticket' voting is common, and polls show consistent support for non-government control of the Senate (Bean \& Wattenburg, 1998). Most recently, only 14 per cent of respondents to the Australian Survey of Social Attitudes approved of the government holding a Senate majority post-2005, while 57 per cent disapproved (Denemark, Meagher, Wilson, Western, \& Phillips, 2007). As in Britain post- 
1999, the Senate tends to reflect partisan voting patterns more closely than does the majoritarian lower house. In some ways it can thus be argued to represent a 'truer' electoral majority. In other words, while the legitimacy of the Senate can be questioned, the legitimacy of the lower house can be brought into relative doubt as well. This helps keep the two chambers in an almost permanent constructive tension, only occasionally interrupted (as in 2005-8) by government Senate control.

The Australian case thus reinforces the conclusions that perceived legitimacy is important to understanding the dynamics of bicameralism, and that its sources are more complex than previously proposed. Even directly elected second chambers can be accused of illegitimacy: both thanks to other compositional factors and, critically, to their fundamental role in challenging 'majority' rule. The perceived legitimacy of second chambers is also relative: lower house majorities can sometimes be questioned too, particularly in systems where these are built on only minority electoral support. ${ }^{26}$

\section{Conclusion: A Three-dimensional Approach}

Lijphart's $(1984,1999$ a) theory of bicameralism has been deservedly influential. $\mathrm{He}$ is unique amongst modern theorists for recognising the relevance of second chamber legitimacy to bicameral strength. This element of his theory was undoubtedly influenced by knowledge of the 'old' pre-1999 House of Lords, and the considerable restraint which it exercised in the twentieth century despite its significant formal powers. But recent developments in Britain have revealed how Lijphart's assumption that the Lords lacked legitimacy solely because of its unelected basis was too simplistic. The 1999 reform demonstrated that some unelected second chambers can be viewed as more legitimate than others, and therefore can exercise their powers more freely.

The central conclusion of this paper is that a convincing theory of bicameral strength needs to be explicitly 'three-dimensional', going beyond formal powers and membership incongruence, to include the perceived legitimacy of the second chamber. Perceived legitimacy critically affects the functioning of bicameralism, yet derives neither from the second chamber's formal powers nor wholly from the extent to which the two chambers' memberships differ. It must therefore be considered as an independent dimension in its own right. Furthermore, a conception of legitimacy based purely on direct election, whereby directly elected second chambers are assumed to be legitimate and strong, and unelected chambers illegitimate and weak, is far too crude. Questions about second chambers' legitimacy can result from various aspects of their mode of composition, but also from their core role of challenging elected first chambers. Democratic 'input' legitimacy may thus not be either necessary or sufficient for such chambers to be respected and influential. As the wider literature suggests, perceptions of legitimacy can be influenced by a combination of input, procedural, and output factors: all three are highly relevant to bicameralism. Public opinion data on attitudes to second 
chambers is often lacking, and what influences opinion is clearly to an extent culturally specific. This undoubtedly creates problems if seeking to present a general theory. But Lijphart's use of direct election as a proxy for legitimacy achieved parsimony at too great a cost to validity.

A secondary point which this paper touches upon, concerning bicameral incongruence, is less original. The evidence from all three cases concurs with a central point made by Tsebelis (2002), and supported by other studies (Druckman \& Thies, 2002; Hiroi, 2008), that party balance is far more crucial to the incongruence dimension than Lijphart acknowledged. Here too cultural factors will play a part. In some settings incongruence of territorial representation may be important in creating friction between the chambers: but only where parliamentarians' territorial identities are sufficiently salient to trump their party identities. Even in federal states, as the Australian case in particular demonstrates, incongruence of partisan representation may matter far more.

A more convincing and widely applicable theory of bicameral strength will therefore see this as influenced by the following three dimensions:

1. The formal powers of the second chamber. Most obviously legislative powers, as set down in constitutional documents.

2. Incongruence of membership between the chambers. Partisan balance will normally be the most important contributor, though other forms of incongruence - territorial, demographic, racial or religious - may also contribute where these are culturally salient.

3. Perceived legitimacy of the second chamber. This depends on public and elite opinion, which in turn may be influenced by a combination of input, procedural and output factors. Crucially, even directly elected second chambers are not guaranteed unqualified support.

This three-dimensional conception is necessarily more general than Lijphart's (1984, 1999a) theory. In cases where there are no serious legitimacy concerns about the second chamber, the first two dimensions will in practice determine de facto bicameral strength. Where both conditions are met, the result may be legislative gridlock - as often occurs in the US under divided government. But since there is often debate about the legitimacy of interventions even by elected second chambers, this does not always apply. For example, in Australia, lingering doubts over legitimacy protect the system from gridlock most of the time.

In essence a properly functioning bicameral system requires the second chamber to have some kind of competing input legitimacy to the first: which may be achieved through different voting systems or other distinct means of composition. The only alternative is two chambers which are essentially identical, thereby breaching the incongruence condition, and resulting in weak bicameralism. But finding a compositional method which is both distinct from that in the first chamber and perceived as sufficiently legitimate is always liable to be challenging. 
The three-dimensional approach offers some novel indications to those facing questions about bicameral design. In Canada, for example, where the formally strong Senate is hampered by legitimacy problems, most reformers assume that building legitimacy depends on moving to an elected Senate. But, as the British case indicates, a great deal might be gained through reforming appointments to create fairer partisan balance and remove discredited prime ministerial patronage (particularly if this were passed to the provincial level). In Britain, too, the House of Lords could be further strengthened by reforming the appointments process to make it more transparently fair. Indeed, various proposals over recent years - including those from a Royal Commission which reported in 2000 - have suggested that the British prime minister's formally unfettered power over appointments should be regulated. ${ }^{27}$ Moves to an elected second chamber on the other hand, if not carefully thought through, could potentially imbue the House of Lords with greater perceived legitimacy than the House of Commons. Hence many groups (including the Royal Commission and the present government) have proposed that elected members should serve long, non-renewable terms of office in order to retain weaker links to the electorate than do MPs. ${ }^{28}$

In general those considering design of bicameral systems must think about the likely salient factors in their own cultural setting regarding both incongruence and perceived legitimacy. As the otherwise 'strong' Australian Senate demonstrates, government politicians may put considerable effort into trying to damage the perceived legitimacy of an assertive second chamber, even if it is elected. Second chambers are by their nature controversial and vulnerable to challenge. This makes effective bicameralism dependent on robust institutional design.

\section{Note on Author}

Meg Russell is Reader in British and Comparative Politics, and Deputy Director of the Constitution Unit, at the Department of Political Science, University College London, email: meg.russell@ucl.ac.uk

\section{Notes}

1. http://www.ipu.org/parline-e/parlinesearch.asp. For a recent overview of second chamber composition and powers see Russell (2012).

2. The Polish Senate can delay bills by just 30 days, after which it can be overridden by an absolute majority of the first chamber. The Irish Senate has a 90-day delay power after which it can be overridden by a simple majority.

3. The Japanese chamber can be overridden only by a two-thirds majority of the lower house; in India disputes must be resolved by a joint session of Parliament.

4. This approach is clearly influenced by US arrangements, but does not reflect practice in most bicameral systems, since only a minority of national second chambers actually possess such a power (Russell, 2012).

5. Even in later periods many second chambers set higher property requirements on either members or voters relative to the first chamber (see section below on Canada for a contemporary example). 
6. Of the remainder, 19 were wholly elected by other means, 19 were only partly elected and 17 contained no elected members at all (Russell, 2012).

7. Indeed the problems of equating legitimacy with direct election were evident even within Lijphart's own analysis, as he noted that the German Bundesrat, whose members are appointed by state governments, is in fact exceptionally strong. Within the context of German federalism, it is clearly considered legitimate for such a chamber to have an assertive role in the policy process.

8. As Michael Saward (1992) points out: 'moral legitimacy may never be reflected accurately in the prevailing state of opinion, or perceived legitimacy... at a given time a morally illegitimate state might be perceived to be legitimate, or vice versa' (p. 47).

9. Lijphart's classification (1984, 1999a) differs between versions. In 1984 the Lords was 'extremely asymmetrical' and in 1999 'asymmetrical': in both cases the lowest ranking on this dimension. In 1999 (although legitimacy was officially part of the symmetry dimension), the Lords dropped half a point on the congruence dimension, for being a 'relic of a predemocratic era' (1999a, p. 213).

10. In 1984 Lijphart had three categories, 'strong', 'weak' and 'insignificant' bicameralism, with Britain ranked 'weak'. In 1999 the categories were 'strong', 'medium-strength' and 'weak', with Britain judged as 'between medium-strength and weak' (1999a).

11. A direct comparison in terms of defeats over time is difficult. Between 1979 and 1992 (under Conservative government) there were 179 government defeats in the House of Lords, but between 1974 and 1979 (under Labour) there were 343. The more important measure may be the extent to which defeats are overturned in the Commons, on which there is little pre-1999 data, and the extent to which the House of Lords insisted on its policy position. For a discussion see Russell (2010).

12. For example, Leader of the House of Lords, Margaret Jay, Lords Hansard, 14 October 1998: col. 925.

13. For example, the Liberal Democrat leader in the House of Lords, Lord McNally, referred to Labour's 'continual plea to the Salisbury convention' in order to get its legislation through the chamber as 'the last refuge of legislative scoundrels' (House of Lords Hansard, 6 June 2005, col. 760). The party leader in the Commons, Charles Kennedy, similarly suggested that it was 'absolutely ridiculous that this Government should now fall back on a 60-year-old convention relating to absolutely different political circumstances' (House of Commons Hansard, 17 May 2005, col. 51).

14. Author's research, funded by ESRC under grant RES-000-23-0597. $N=381$ (response rate 52 per cent). Although it was Labour in government that had publicly pronounced the reformed chamber to be 'more legitimate', this belief was expressed consistently by all party groupings (and independents) across the House.

15. Author's research, funded by Leverhulme Trust. $N=195$ (response rate 30 per cent).

16. For example, a survey commissioned by the Hansard Society in 2007 found that only 5 per cent of respondents felt that they understood the House of Lords 'very well', and 33 per cent 'fairly well'.

17. Author's research, funded by ESRC under grant RES-000-23-0597 (1007 valid respondents, with results adjusted to be demographically and politically representative).

18. Author's research carried out by Mori, funded by ESRC under grant RES-000-23-0597 (2044 valid respondents, with results adjusted to the demographically and politically representative). On 'doing a good job', figures for entire sample were 57 per cent for Lords and 53 per cent for Commons, and 66 per cent and 57 per cent respectively amongst those claiming to know 'a great deal' or 'quite a lot' about the Westminster parliament. On the 'process for choosing members' the figures were 36 per cent for Lords and 62 per cent for Commons, changing to 34 per cent versus 64 per cent respectively amongst more knowledgeable respondents.

19. A further question from the same poll supports this: when specifically asked 'which factors are important to determining Lords' legitimacy', 73 per cent believed that it was very important 'that the House considers legislation carefully and in detail' (procedural legitimacy), while only 50 per cent said the same of the proposition that there should be 'some members elected by the public' (democratic input legitimacy).

20. For Canada (and Australia) we are more dependent on expert opinion and anecdotal evidence with respect to perceived legitimacy than for the UK, where polls have been commissioned explicitly on this question.

21. Environics Focus Canada survey 1987-4, September 1987, 2013 respondents: 46 per cent were in favour and 34 per cent against; don't knows were 20 per cent. 
22. Each state originally had six seats, but now has 12 . Two seats for each of the two territories were added later.

23. Lijphart himself noted the importance of the two Australian chambers' distinct electoral systems, but suggested that this simply 'reinforces their incongruence' for which they 'already qualify ... as a result of equal representation of the states in the Senate' (1999b, p. 315). Subsequent events (and indeed the situation pre-1948) show this reasoning to have been flawed.

24. Parliamentary Debates, 5 November 1992.

25. Speech to Bicameralism: Australia in Comparative Perspective conference, Canberra: Parliament House, 9-10 October 2008. At http://www.aph.gov.au/senate/pubs/pops/pop50/the_senate_ blessing_or_bane.htm (accessed 16 February 2012).

26. This is a point made by Riker (1992), who suggests that bicameralism may not only be a protection against majority tyranny, but also against minority tyranny when the lower house majority does not reflect a real electoral majority. But of course there is no guarantee that the upper house majority is any more representative of public opinion: this will depend on the detail of its composition. In both Australia and the UK this happens to be the case.

27. See for example Royal Commission on the Reform of the House of Lords (2000), Public Administration Select Committee (2002, 2007), Russell et al. (2011).

28. For the government's most recent proposals, which included a short white paper as well as a bill, see Cabinet Office (2011). These reforms failed: see Russell (2013).

\section{References}

Bach, S. (2008). Crisp, the Senate, and the constitution. Australian Journal of Political Science, 54(4), $545-561$.

Bagehot, W. (1867/2001). The English Constitution. Oxford: Oxford University Press.

Baird, V. A. (2001). Building institutional legitimacy: The role of procedural justice. Political Research Quarterly, 54, 333-354.

Barker, R. S. (1990). Political legitimacy and the state. Oxford and New York: Oxford University Press.

Bean, C. S., \& Wattenburg, M. P. (1998). Attitudes towards divided government and ticket-splitting in Australia and the United States. Australian Journal of Political Science, 33(1), 25-36.

Beetham, D. (1991). The legitimation of power. New York: Palgrave Macmillan.

Beetham, D., \& Lord, C. (1998). Legitimacy and the EU. Harlow: Addison-Wesley Longman.

Bodansky, D. (1999). The legitimacy of international governance: A coming challenge for international environmental law? The American Journal of International Law, 93(3), 596-624.

Cabinet Office (2011). House of Lords reform draft bill. London: The Stationery Office.

Crisp, L. F. (1983). Australian national government. Melbourne: Longman Cheshire.

Denemark, D., Meagher, G., Wilson, S., Western, M., \& Phillips, T. (2007). A changing Australia II: The public disapproves of senate majority. In D. Denemark (Ed.), Australian social attitudes II: Citizenship, work and aspirations. Sydney: UNSW Press.

Dogan, M. (1995). Testing concepts of legitimacy and trust. In H. E. Chehabi \& A. Stepan (Eds.), Politics, society and democracy (pp. 57-71). Boulder, CO: Westview.

Druckman, J. N., \& Thies, M. F. (2002). The importance of concurrence: The impact of bicameralism on government formation and duration. American Journal of Political Science, 46, 760-771.

Evans, H. (2008). The senate, accountability and government control. Parliamentary Studies Paper 4. Canberra: Crawford School of Economics and Government, Australian National University.

Flinders, M. V. (2005). Majoritarian democracy in Britain: New Labour and the constitution. West European Politics, 28(1), 61-93.

Forsey, E. A. (1982). The Canadian Senate. The Parliamentarian, 63(3), 270-276.

Franks, C. E. S. (1999). Not dead yet, but should it be resurrected? In S. C. Patterson \& A. Mughan (Eds.), Senates: Bicameralism in the contemporary world (pp. 120-161). Columbus: Ohio State University Press.

Franks, C. E. S. (2003). The Canadian Senate in modern times. In S. Joyal (Ed.), Protecting Canadian democracy: The Senate you never knew (pp. 152-188). Montreal: McGill-Queen's University Press.

Goot, M. (1999). Whose mandate? Policy promises, strong bicameralism and polled opinion. Australian Journal of Political Science, 34(3), 327-352. 
Heller, W. B. (2001). Political denials: The policy effect of intercameral partisan differences in bicameral parliamentary systems. Journal of Law, Economics and Organization, 17, 34-61.

Hibbing, J. R., \& Theiss-Morse, E. (1995). Congress as public enemy: Public attitudes toward American political institutions. Cambridge and New York: Cambridge University Press.

Hiroi, T. (2008). The dynamics of lawmaking in a bicameral legislature: The case of Brazil. Comparative Political Studies, 41(12), 1583-1606.

King, A. (2007). The British Constitution. Oxford: Oxford University Press.

Lijphart, A. (1984). Democracies: Patterns of majoritarian and consensus government in twenty-one countries. New Haven, CT: Yale University Press.

Lijphart, A. (1999a). Patterns of democracy: Government forms and performance in thirty-six countries. New Haven, CT: Yale University Press.

Lijphart, A. (1999b). Australian democracy: Modifying majoritarianism? Australian Journal of Political Science, 34, 313-326.

Lipset, S. M. (1959). Some social requisites of democracy: Economic development and political legitimacy. The American Political Science Review, 53(1), 69-105.

Llanos, M., \& Nolte, D. (2003). Bicameralism in the Americas: Around the extremes of symmetry and incongruence. The Journal of Legislative Studies, 9(3), 54-86.

Majone, G. (1998). Europe's 'democratic deficit': The question of standards. European Law Journal, 4(1), 5-28.

Menon, A., \& Weatherill, S. (2008). Transitional legitimacy in a globalising world: How the European Union rescues its states. West European Politics, 31(3), 397-416.

Mezey, M. L. (1979). Comparative legislatures. Durham, NC: Duke University Press.

Mill, J. S. (1861/1998). On liberty and other essays. Oxford: Oxford University Press.

Mondak, J. J. (1994). Policy legitimacy and the Supreme Court: The sources and contexts of legitimation. Political Research Quarterly, 47(3), 675-692.

Money, J., \& Tsebelis, G. (1992). Cicero's puzzle: Upper house power in comparative perspective. International Political Science Review, 13(1), 25-43.

Mulgan, R. (2000). The mandate: A response to Goot. Australian Journal of Political Science, 35(2), 317-322.

Papadopoulos, Y., \& Warin, P. (2007). Are innovative, participatory and deliberative procedures in policy making democratic and effective? European Journal of Political Research, 46(4), 445-472.

Patterson, S. C., \& Mughan, A. (1999). Senates and the theory of bicameralism. In S. C. Patterson \& A. Mughan (Eds.), Senates: Bicameralism in the contemporary world (pp. 1-31). Columbus: Ohio State University Press.

Public Administration Select Committee (2002). The second chamber: Continuing the reform. London: House of Commons.

Public Administration Select Committee (2007). Propriety and peerages: Second report of session 2007-08. London: House of Commons.

Riker, W. H. (1992). The justification of bicameralism. International Political Science Review, 13(1), $101-116$.

Rogers, J. R. (2001). An informational rationale for congruent bicameralism. Journal of Theoretical Politics, 13, 123-152.

Royal Commission on the Reform of the House of Lords (2000). A house for the future. London: HMSO.

Russell, M. (2000). Reforming the House of Lords: Lessons from overseas. Oxford: Oxford University Press.

Russell, M. (2001). The territorial role of second chambers. The Journal of Legislative Studies, 7(1), $105-118$.

Russell, M. (2010). A stronger second chamber? Assessing the impact of House of Lords reform in 1999, and the lessons for bicameralism. Political Studies, 58(5), 866-885.

Russell, M. (2012). Elected second chambers and their powers: An international survey. The Political Quarterly, 83(1), 117-129.

Russell, M. (2013 forthcoming). The contemporary House of Lords: Westminster bicameralism revived. Oxford: Oxford University Press.

Russell, M., \& Sciara, M. (2007). Why does the government get defeated in the House of Lords? The Lords, the party system and British politics. British Politics, 2, 299-322. 
Russell, M., \& Sciara, M. (2008). The policy impact of defeats in the House of Lords. British Journal of Politics and International Relations, 10(4), 571-589.

Russell, M., Adonis, A., Allen, G., Boothroyd, B., Butler, R., Dean, B., \& Wright, T. (2011). House full: Time to get a grip on Lords appointments. London: Constitution Unit.

Sartori, G. (1994). Comparative constitutional engineering: An inquiry into structures, incentives and outcomes. London: Macmillan Press.

Saward, M. (1992). Co-optive politics and state legitimacy. Aldershot: Dartmouth.

Sharman, C. (1999). The representation of small parties and independents. In M. Sawer \& S. Miskin (Eds.), Representation and institutional change: 50 years of proportional representation in the Senate (pp. 149-158). Canberra: Department of the Senate.

Shell, D. (1999). To revise and deliberate: The British House of Lords. In S. C. Patterson \& A. Mughan (Eds.), Senates: Bicameralism in the contemporary world (pp. 199-224). Columbus: Ohio State University Press.

Shell, D. (2007). The House of Lords. Manchester: Manchester University Press.

Siaroff, A. (2003). Varieties of parliamentarianism in the advanced industrial democracies. International Political Science Review, 24(4), 445-464.

Simmons, A. J. (2001). Justification and legitimacy: Essays on rights and obligations. Cambridge: Cambridge University Press.

Tsebelis, G. (2002). Veto players: How political institutions work. Princeton, NJ: Princeton University Press.

Tsebelis, G., \& Money, J. (1997). Bicameralism. Cambridge: Cambridge University Press.

Tyler, T. R., \& Rasinski, K. (1991). Procedural justice, institutional legitimacy, and the acceptance of unpopular U.S. Supreme Court decisions: A reply to Gibson. Law and Society Review, 25(3), $621-629$.

Vibert, F. (2007). The rise of the unelected: Democracy and the new separation of powers. Cambridge: Cambridge University Press.

Weber, M. (1957). The theory of social and economic organization. Glencoe, IL: Free Press. 